\title{
IbM Kerajinan \\ Pengerajin Logam di Desa Beratan Buleleng Bali
}

Oleh:

I Ketut Supir, dkk

\section{Abstrak}

Desa Beratan salah satu desa di kabupaten Buleleng yang menjadi pusat kerajinan logam (emas, perak, dan kuningan). Kerajinan logam desa Beratan pernah mengalami masa keemasan dan sejak bom Bali I dan bom Bali II, meledak, kerajinan ini mengalami kemerosotan seiring dengan lesunya industri pariwisata di Bali. Sebagian besar pengerajin beralih ke pekerjaan lain, dan saat ini ada tiga orang pengerajin yang masih setia menggeluti kerajinan. Ketiganya menghadapi masalah yang sama, yaitu bidang produksi, manajemen, dan pemasaran. Peralatan yang dimiliki pengerajin masih tradisional dan sudah tua. Pengerajin tidak memiliki pembukuan dan dokumentasi produk yang telah dibuat. Pemasaran produk sangat terbatas.

Solusi yang dapat dilakukan dalam menjawab permasalahan tersebut, yaitu: (1) memodifikasi alat peleburan/pencairan emas dan perak yang digerakkan dengan tenaga listrik; (2) pengadaan alat-alat pendukung proses produksi, antara lain: bor listrik yang dapat membantu percepatan dalam proses produksi; (3) pelatihan penganekaragaman desain produk kerajinan sesuai perkembangan pasar; (4) pelatihan manajemen usaha berbasis komputer, dan perancangan dan pembuatan website atau ecommerce.

Peralatan elektik sangat membantu pengerajin dalam menhemat tenaga, waktu, dan dapat meningkatkan kuantitas dan kualitas produksi. Pelatihan desain menambah wawasan pengerajin dalam menghadapi tren pasar.

Kata Kunci: Logam, Emas, Perak, Desa Beratan, Kerajinan.

\begin{abstract}
Beratan village one of the villages in the district at the center of craft Buleleng metals (gold, silver, and brass). Beratan metal crafts village has experienced a golden age, and since the Bali bombing I and the Bali bombing II, explode, the craft is in decline due to sluggish tourist industry in Bali. Most of the craftsmen switched to
\end{abstract}


another job, and now there are three craftsmen who still cultivate the craft. All three face the same problem, namely the production, management, and marketing. Equipment owned by the craftsmen still traditional and old. Craftsmen did not have the bookkeeping and documentation of products that have been made. Marketing of products is very limited.

Solution that can be done in answer to these problems, namely: (1) modify the fusion device / melting gold and silver which is driven by electric power, (2) the procurement of tools supporting the process of production, among others: a power drill that can help accelerate the process production, (3) training of appropriate diversification of product design craft market development, (4) computer-based training in business management, and design and manufacture or ecommerce website.

Eclectic equipment helps craftsmen in saving energy, time, and can increase the quantity and quality of production. Broaden the training design craftsmen in the face of market trends.

Keywords: Metals, Gold, Silver, Beratan village, Craft.

\section{Pendahuluan}

Desa Beratan salah satu desa sebagai pusat kerajinan logam (emas dan perak) di kabupaten Buleleng. Kapan kerajinan logam desa Beratan dimulai, , belum diketahui secara pasti. Namun, kerajinan ini sudah dikenal masyarakat sejak zaman kerajaan Buleleng. Profesi sebagai pengerajin logam, dalam masyarakat Bali, dilakukan oleh keturunan pande, nama dari salah satu klan (soroh). Masyarakat Bali terdiri atas lapisan yang oleh Wiana (1993: 12) disebut dengan warna atau wangsa (brahmana, ksatria, wesya, dan sudra), yang sebenarnya didasarkan atas pembagian tugas yang diaplikasikan dalam (kewajiban (guna) dan perbuatan (karma). Tiga lapisan pertama disebut triwangsa (Ida Bagus, Anak Agung, dan I Gusti), dan klan pande ada di luar triwangsa itu. Klan pande bertugas menyediakan peralatan dan perabotan yang terbuat dari logam—keris, alat pertanian, rumah tangga, sampai asesoris. Di desa Beratan, sebagian besar masyarakatnya adalah keturunan klan pande-yang diduga berasal dari daerah sekitar Danau Beratan, Bedugul, kabupaten Tabanan-secara khususnya membuat perlengkapan upacara agama Hindu, dan perhiasan dari emas dan perak (cincin, kalung, subang, dan sebagainya) (Sugriwa, 1958:4). 
Kerajinan logam Desa Beratan sempat menikmati masa jaya seiring dengan perkembangan industri pariwisata di Bali. Pengerajin, ketika itu, banyak menerima pesanan baik dari konsumen lokal maupun mancanegara. Produk kerajinan logam lebih banyak diarahkan pada benda cenderamata untuk memenuhi kebutuhan wisatawan. Setelah Bom Bali I meledak di Kuta, kemudian disusul oleh Bom Bali II, industri pariwisata Bali mangalami lumpuh total. Kondisi ini berpengaruh pada industri kecil yang bergantung pada pariwisata, termasuk kerajinan logam Desa Beratan yang mati secara pelan-pelan.

Sejurus dengan kebutuhan hidup dalam keluarga terus meningkat, menjadi penyebab hampir semua pengerajin yang dulu sukses, beralih kepada pekerjaan lain yang lebih menjajikan. Para remaja laki-laki Desa Beratan banyak yang meninggalkan desanya untuk bekerja di Kapal Pesiar, mereka tidak bangga lagi menjadi pengerajin logam. Terkait dengan klan pande dalam masyarakat Bali yang bertugas membuat benda-benda dari logam-untuk fungsi keagamaan dan fungsi sekuler-yang telah diwarisi secara turun-temurun ditinggalkan begitu saja.

Dalam kondisi yang sangat memprihatinkan ini, masih ada segelintir pengerajin yang masih setia mempertahankan warisi nenek moyangnya. Mereka adalah (1) I Ketut Dibya (75 tahun), (2) Ketut Widiana (48 tahun), dan (3) I Nyoman Suweden (43 tahun). Ketiga penegrajin itu masih dalam satu keluarga-seorang bapak dan dua orang anaknya - tetapi mereka mengelola usahanya sendiri-sendiri. Beberapa alasan kenapa mereka masih menekuni kerajinan logam, pertama, karena faktor umur, tidak mungkin mereka pergi ke luar desa mencari pekerjaan lain. Kedua, mereka masih setia menjunjung bhisama (keputusan) leluhurnya untuk terus menekuni profesi sebagai pande.

Pengerajin logam desa Beratan, dalam berproduksi, menghadapi berbagai persoalan yang menyebabkan produksinya secara kuantitas maupun kualitas belum mampu bersaing di pasaran. Persoalan-persoalan yang dihadapi, antara lain, dalam bidang produksi, bidang manajemen, dan pemasaran. Permasalahan produksi yang paling mendesak, antara lain: (a) alat peleburan/pencairan emas dan perak, yang selama ini, pengoperasiannya dilakukan secara manual menyebabkan proses produksi lambat dan cukup menguras tenaga; (b) alat penggiling manual yang kondisinya sudah tua, beberapa komponennya sudah haus sehingga tidak bisa menghasilkan benangbenang emas dan perak dengan baik; (c) bor dan alat kilap manual sangat menghambat proses produksi. 
Masalah desain merupakan persoalan yang sangat dirasakan pengerajin. Pengetahuan dan kemampuan dalam desain yang dimiliki sangat terbatas pada desain tradisional, sehingga produk yang dibuat monotun tidak mampu mengikuti selera pasar. Sebenarnya, kemampuan teknis yang dimiliki pengerajin cukup baik dan bebrapa motif ukiran kerajinan logam Desa Beratan memiliki gaya tersendiri, tetapi itu tidak cukup untuk menghadapi selera pasar yang selalu berubah.

Pemisahan manajemen keuangan usaha dan rumah tangga tidak jelas, sehingga mereka tidak mengetahui apakah usahanya dalam keadaan untung atau rugi. Demikian pula, pengerajin tidak memiliki dokumentasi produk yang telah dihasilkan, ini juga menjadi sebab rendahnya keyakinan pemesan terhadap kemampuan pengerajin.

Pengerajin tidak pernah melakukan promosi terhadap produk yang dihasilkan, baik di media cetak maupun media elektronik. Mereka juga tidak pernah mengikuti atau diikutsertakan dalam pameran baik di dalam maupun di luar negeri. Pemasaran produknya terbatas dan mampu menerima pesanan dalam jumlah kecil. Mitra juga belum memiliki website/ecommerce sebagai media promosi/took online.

Permasalahan yang dihadapi pengerajin merupakan penyebab laten terhadap keberlangsungan hidup kerajinan logam Desa Beratan. Permasalah ini menjadi inspirasi dalam melakukan kegiatan P2M ini, yang bertujuan:

1. Mengatasi masalah peralatan yang hampir semuanya masih bekerja secara manual. Kondisi alat yang sebagian sudah tua dan haus, tidak mampu menghasilkan produk yang maksimal dalam jumlah maupun kualitas.

2. Mengatasi keterbatasan desain kerajinan emas dan perak desa Beratan yang cendrung monotun dari tahun ke tahun. Kondisi ini sangat berbanding terbalik dengan kekuasaan pasar, sekarang ini, yang menghendaki desain-desain yang inovatif dan menarik.

3. Perluasan sistem pemasaran, yang selama ini, hanya menunggu pembeli datang ke rumah. Jaringan pasar masih terbatas dalam lingkup lokal.

\section{Metode}

Metode penerapan IPTEKS dalam pengabdian ini adalah (1) Metode observasi dan Wawancara; (2) Metode Penyuluhan dan pelatihan. Penerapan metode ini dilakukan secara terpisah dan secara bersama terkombinasi. 


\section{Metode Observasi dan Wawancara}

Pembinaan terhadap pengerajin emas dan perak desa Beratan dilakukan secara bertahap. Sebelum pelaksanaan program dilakukan observasi dan wawancara dengan menerapakan model partisipatory rural apprasial. Model ini digunakan untuk mengidentifikasi masalah yang dialami mitra atau kelompok masyarakat. Dalam merumuskan masalah, mengatasi masalah, penentuan proses dan kriteria masalah harus, mitra harus diikutsertakan. Penggunaan model pendekatan ini diharapkan akan: (1) dikenalnya masalah secara tepat/efektif sesuai dengan persepsi, kehendak, dan ukuran/kemampuan serta kebutuhan mereka, (2) tumbuhnya kekuatan (enpowering) masyarakat atau kelompok sasaran dalam pengalaman merancang, melaksanakan, mengelola dan mempertanggungjawabkan sebagai upaya peningkatan/pertumbuhan diri dan ekonominya, dan (3) efektifitas dan efisiensi penggunaan sumber daya mitra atau kelompok masyarakat. Observasi dilakukan terus menerus sejalan dengan setiap langkah yang akan ditempuh.

\section{Metode Penyuluhan dan Pelatihan}

Penyuluhan dan pelatihan dilakukan dalam bidang manajemen dan bidang desain. Penumbuhan kesadaran pengerajin tentang pentingnya pencatatan dan pendokumentasian produk yang telah dibuat. Pendokumentasian produk adalah cara efektif dalam meyakinkan calon konsumen, yakni dengan memperlihatkan gambar produk yang telah dibuat dalam bentuk album atau barang aslinya. Dalam kegiatan ini diterapkan model enthrepreneurship capasity building (ECB), model Teknologi Tepat Guna (TTG), model Technology Transfer (TT), dan model Information Technology (IT). Model ECB terkait erat dengan kemampuan berwirausaha dari mitra. Dengan model ini diharapkan: (1) memberikan wawasan, sikap, dan keterampilan usaha, (2) memberikan peluang, (3) memfasilitasi (modal pinjamaan dsb.), dan (4) memonitor dan mengevaluasi bagaimana perkembangan usahanya. Model Technology Transfer (TT). Model TT dilakukan agar mitra atau kelompok masyarakat menguasai prinsipprinsip penerapan teknologi terutama yang berkaitan dengan program yang sedang/akan dilaksanakan. Model Teknologi Tepat Guna (TTG) digunakan jika teknologi yang diterapkan dirasakan terlalu rumit untuk menyelesaikan masalah/kebutuhan mereka. Model Information Technology (IT) digunakan untuk menyebarluaskan informasi dan sosialisasi program dengan hasil penerapan TTG yang cukup layak dikemas dalam bentuk kemasan informasi media cetak/elektronik. 
Dengan demikian, model IT dalam program IbM ini digunakan untuk menyebarluaskan hasil modifikasi TTG yang aplikasinya benar-benar telah teruji secara layak.

\section{Hasil Dan Pembahasan}

Tiga persoalan pokok yang dihadapi pengerajin logam, yakni masalah peralatan, manajemen, dan pemasaran. Masalah alat yang dibutuhkan oleh pengerajin diatasi dengan cara membelikan alat baru dan memodifikasi alat manual menjadi alat yang digerakkan dengan tenaga listrik. Alat yang dibeli baru, seperti bor listrik, alat polis listrik, dan perangkat komputer, sedang alat yang dimodifikasi, seperti alat pompa yang semula manual diubah menjadi alat yang digerakkan dengan tenaga listrik. Kegiatan program P2M menerapkan model TTG dengan membuat alat sederhana yang dapat menyelesaikan masalah atau kebutuhan pengerajin. Perangkat komputer diberika kepada pengerajin, memang dalam jangka pendek pengerajin belum bisa menggunakan secara maksimal, tetapi dalam jangka panjang, perangkat komputer dapat digunakan oleh pengerajin bersama anaknya membuat mengaplud barang produksinya melalui Website dan digunakan belajar membuat desain.

Penyuluhan dan pelatihan manajemen dilaksanakan sesuai dengan jadwal yang telah disepakati bersama dengan materi pembuatan pembukuan sederhana, yakni mampu mencatat pengeluaran dan pendapatan. Pelatihan desain lebih ditekankan pada pengembangan ide-ide dan penguasaan keterampilan (skill) dalam mendesain. Di selasela praktik membuat desain disisipkan pula pengetahuan tentang desain—pengertian, fungsi, sejarah desain logam, dan makna desain. Desain yang telah dirancang, dipilih, kemudian diwujudkan sesuai dengan kemampuan teknik yang dikuasai. Instruktur bersama pengerajin mengevaluasi karya yang telah dihasilkan untuk melihat kelemahan dan keunggulannya, tujuannya agar pengerajin mampu menilai karya sendiri dengan objektif.

Pemasaran produk diterapkan dengan model Information Technology (IT) untuk menyebarluaskan informasi dan sosialisasi tentang hasil produksi logam secara luas. Namun demikian, pemasaran lokal dan pesanan masih tetap menjadi perhatian. Beberapa produk yang dihasilkan selama program ini mendapatkan peminat meskipun masih dalam wilayah terbatas.

Pelatihan ini mendapat apresiasi baik dari pengerajin. Mereka sangat antusias mengikuti kegiatan ini. Tiga orang pengerajin ini yang akan menjadi pioner dalam 
menggairahkan kembali kerajinan emas dan perak Desa beratan yang hampir punah ini. Melalui mereka bertiga, diharapkan mantan pengerajin yang lain tertarik menggeluti kembali kerajinan ini, sehingga ke depan keluarga Pande desa Beratan bisa mengidupi dirinya dari profesi sebagai pengerajin, selain dalam usaha melanjutkan bhisama leluhurnya.

Di bawah ini, ditampilkan beberapa gambar desain dan perwujudannya selama pelaksanaan program IbM, sebagai berikut.

Desain dalam proses perwujudan karya. Mendesain adalah langkah pertama yang harus dilakukan pengerajin. Rancangan desain terdapat dalam pikiran pengerajin yang langsung diwujudkan dalam bentuk produk jadi. Ada rancangan desain dibuat di atas kertas dengan teknik manual atau menggunakan bantuan komputer, tujuan agar setiap saat dapat digunakan sebagai acuan ketika mewujudkannya.

Pin dan cincin Ganesha berbahan emas, perak, tembaga, dan kuningan. Pin lambang Undiksha dirancang untuk dijual kepada mahasiswa Undiksha. Desain pin ini juga dengan ukuran yang lebih besar berbahan kuningan atau tembaga yang diberikan kepada setiap wisudawan Undiksha.Cincin ganesha dipasarkan kepada masyarakat umum sebagai cenderamata.

Perhiasan bros, cincin, mainan kalung, subang dengan teknik trap-trapan cukup di minati oleh konsumen lokal Bali maupun oleh touris manca negara. Gagang keris diproduksi untuk memenuhi permintaan para pembuat keris yang belakang ini banyak dipesan oleh konsumen mancanegara.

\section{SIMPULAN}

Dari uraian di atas dapat disimpulkan bahwa kegiatan IbM kerajinan yang dilaksanakan terhadap pengerajin logam di Desa Beratan, Kecamatan Buleleng, Kabupaten Buleleng telah berlangsung dengan lancar. Dalam program ini diserahkan kepada pengerajin peralatan dibutuhkan untuk mendukung proses produksi. Berakhirnya program ini, pengerajin dapat membuat pembukuan sederhana dan mampu merancang desain logam serta mewujudkannya. Pemasaran barang kerajinan melalui Web telah mampu dilakukan oleh pengerajin.

\section{Ucapan Terima Kasih}


Ucapan terima kasih dan penghargaan yang tinggi disampaikan kepada pengerajin emas dan perak Desa beratan Buleleng. Ucapan yterima kasih yang setinggi-tinginya juga dihaturkan kepada DP2M DIKTI atas dana Hibah Program Pengabdian IbM tahun 2011, Rektor Undiksha atas izin dan dorongannya selama ini, Ketua LPM Undiksha, rekan-rekan dosen di Jurusan Pendidikan Seni Rupa, FBS yang selalu memberikan semangat dan medorong penulis untuk melakukan kegiatan P2M ini.

\section{DAFTAR PUSTAKA}

Sugriwa, I Gusti Bagus. 1958. Prasasti Pande. Denpasar: Pustaka Balimas

Wiana, Ketut. 1993. Kasta dalam Hindu: Keslahpahaman Berabad-abadDenpasar: Yayasan Dharma Naradha 